\title{
FIBROADENOMA IN AN ECTOPIC BREAST TISSUE
}

\section{Vinod Tamaknand ${ }^{1}$, Devender Choudhary², Bhawan Nangarwal ${ }^{3}$, Rajesh Godara4, Pradeep Garg ${ }^{5}$}

1 Junior Resident, Department of Surgery, PGIMS.

2Junior Resident, Department of Surgery, PGIMS.

3Junior Resident, Department of Surgery, PGIMS.

${ }^{4}$ Professor, Department of Surgery, PGIMS.

${ }^{5}$ Senior Professor, Department of Surgery, PGIMS.

\section{ABSTRACT}

Ectopic breast tissue may be affected by the same diseases and alterations that affect topical breast tissue. Nevertheless, reports of fibroadenoma of the axilla are rare.

\section{OBJECTIVE}

To describe a case of fibroadenoma in an axillary ectopic breast tissue.

\section{CASE REPORT}

A 21 yrs. old woman presented with mass in left axilla since 1 yr., which was gradually increasing in size and not associated with menstrual cyclical disturbance. $0 / \mathrm{E}$ : Lump of size $4 \times 3$ present in left axilla, mobile and non-tender. Breast USG and mammography was reported normal. HPE revealed findings consistent with fibroadenoma.

\section{KEYWORDS}

Fibroadenoma, Ectopic Breast Tissue

HOW TO CITE THIS ARTICLE: Tamaknand V, Choudhary D, Nangarwal B, et al. Fibroadenoma in an ectopic breast tissue. J. Evolution Med. Dent. Sci. 016;5(47):3034-3035, DOI: 10.14260/jemds/2016/706

\section{INTRODUCTION}

An axillary swelling presenting as ectopic breast may not always be a normal breast tissue. It can be associated with pathological anomalies like inflammation, fibrosis, fibroadenoma, cystosarcoma phyllodes and carcinoma. Supernumerary nipple (Polythelia) and supernumerary breast (Polymastia) are common anomalies of breast. They develop along embryonic milk line from axilla to inguinal region. 1,2 The incidence ranges from 1-6\%.3 They have been reported in areas other than milk line region such as vulva, face and perineum. Fibroadenoma is a benign disease of normal breast tissue, which rarely occurs in an ectopic breast. Only few cases have been reported in literature. These anomalies are often associated with congenital anomalies of urinary and cardiovascular system. ${ }^{4}$ We report a case of fibroadenoma in ectopic breast tissue to highlight the importance of proper examination of ectopic breast tissue and its pathological anomalies.

\section{CASE REPORT}

A 21 yr. old woman presented with a mass in left axilla since one year, which was gradually increasing in size and not associated with pain or menstrual cycle disturbance. On examination a lump of size $4 \times 3 \mathrm{~cm}$ was present in left axilla, completely separated from left breast. Swelling was firm in consistency with a $3 \times 2 \mathrm{~cm}$ size hard tissue within the lump. Lump was mobile and non-tender.

\section{Financial or Other, Competing Interest: None}

Submission 07-04-2016, Peer Review 20-05-2016,

Acceptance 26-05-2016, Published 13-06-2016.

Corresponding Author:

Dr. Devender Choudhary,

Room No. 336,

Doctor's Hostel

PGIMS, Rohtak

E-mail: devinderkuntal@gmail.com

DOI: 10.14260/jemds/2016/706
Bilateral breast and axillary examination revealed no findings. No biopsy or cytological study of mass was performed. Breast USG and mammography was reported normal. Lump was excised under general anaesthesia and sent for histopathological reporting with provisional diagnosis of fibroadenoma in ectopic breast tissue. Histopathological report confirmed features of fibroadenoma. Sections passed through fibrofatty tissue showed fibrosis, adenosis, and fibroadenomatoid changes.

\begin{tabular}{|c|c|c|c|}
\hline Class & Nipple & Areola & $\begin{array}{c}\text { Glandular } \\
\text { Tissue }\end{array}$ \\
\hline I & + & + & + \\
\hline II & + & - & + \\
\hline III & - & + & + \\
\hline IV & - & - & + \\
\hline V & + & + & - \\
\hline VI (Polythelia) & + & - & - \\
\hline $\begin{array}{c}\text { VII (Polythelia } \\
\text { Areolaris) }\end{array}$ & - & + & - \\
\hline $\begin{array}{c}\text { VIII (Polythelia } \\
\text { Pilosa) }\end{array}$ & \multicolumn{4}{|c|}{ A Patch of Hair Only } \\
\hline Table 1: Kajava Classification of Ectopic Breast Tissue \\
\hline
\end{tabular}

\section{DISCUSSION}

Supernumerary nipple and supernumerary breast are common ectopic breast diseases described in literature.5,6 Ectopic breast tissue can be present anywhere along embryonic milk line extending from axilla-to-inguinal region. Embryonic milk line develops during $6^{\text {th }}$ week of embryonic development by thickening of ectodermal layer thus giving origin to normal breast tissue in pectoral region. There are two theories for development of ectopic breast tissue. One postulates failure of regression and displacement of milk line. ${ }^{7}$ Second theory suggests development from modified apocrine sweat gland. ${ }^{8}$ Incidence of accessory breast is $0.4-6 \%$ in 
females. ${ }^{4} 67 \%$ accessory breast present in thoracic and abdominal area and $20 \%$ present in axilla along milk line.

Other sites are face, vulva and perineum. Time of presentation are different for supernumerary nipple and supernumerary breast. Supernumerary nipple can be present at birth, but supernumerary breast develops after hormonal stimulation usually during puberty, pregnancy and lactation. ${ }^{9}$ Ectopic breast tissue was classified into 8 classes by Kajava in 1915.10

Usually ectopic breast tissue occurs sporadically, but a hereditary predisposition has also been reported. Study of American population by Gilmore et al found that incidence of ectopic breast tissue is more common in native Americans than in non-Americans. ${ }^{11}$ These indicate role of genetic basis in development of ectopic breast tissue. Apart from cosmetic and psychological disturbances, the pathological changes in ectopic breast tissue are same as in normal breast tissue such as inflammation, fibrosis, fibroadenoma, cystosarcoma phyllodes and carcinoma. ${ }^{12,13}$ Ectopic breast tissue is often associated with congenital anomalies of urogenital system. Malignancy of ectopic breast tissue without nipple poses diagnostic challenge resulting in earlier and frequent metastasis with poor prognosis.

\section{CONCLUSION}

In case of any swelling in milk line, evaluation should rule out fibroadenoma and associated urogenital anomalies. Investigation for benign and malignant pathology in ectopic breast tissue should be done timely.

\section{REFERENCES}

1. Moore KL, Persaud TVN. The developing human: clinically oriented embryology. Philadelphia (USA): WB Saunders 1993; $5^{\text {th }}$ edn:448-450.
2. McLachlan J. Medical embryology. Wokingham (England): Addison-Wesley 1994;1 $1^{\text {st }}$ edn:141-142.

3. Haagenson CD. Diseases of the breasts.. Philadelphia (USA): WB Saunders 1986; 3 ${ }^{\text {rd }}$ edn:5-7.

4. Coras B, Bulbuloglu E, Arican O, et al. Fibroadenoma of the ectopic breast axilla- a case report. Pol J Pathol 2006;57(4):209-211.

5. Dixon JM, Mansel RE. ABC of breast diseases: congenital and aberrations of normal breast development and involution. BMJ 1994;309(6957):797-800.

6. Grossl NA. Supernumerary breast tissue: historical perspectives and clinical features. South Med J 2000;93(1):29-32.

7. Hanson E, Segovia J. Dorsal supernumerary breast. Case report. Plastic Reconstr Surg 1978;61(3):441-445.

8. Craigmyle MB. The apocrine glands and the breast. New York (USA): Wiley 1984;49-55.

9. Burdick AE, Thomas KA, Welsh E, et al. Axillary polymastia. J Am Acad Dermatol 2003;49(6):1154-1156.

10. Kajava Y. The proportions of supernumerary nipple in the finnish population. Duodecim 1915;1:143-170.

11. Glimore HT, Milory M, Mellow BJ. Supernumerary nipples and accessory breast tissue. SDJ Med 1996;49(5):149-51.

12. Rizvi G, Pandey H, Gupta MK. Fibroadenoma of ectopic breast tissue in axilla. Journal of case reports 2012;2(2):13-15.

13. Shin SJ, Sheikh FS, Allenby PA, et al. Invasive secretory (juvenile) carcinoma arising in ectopic breast tissue of axilla. Archives of Pathology and Laboratory Medicine 2001;125(10)1372-4. 